\title{
Patient Preference for Care Action
}

National Cancer Institute

\section{Source}

National Cancer Institute. Patient Preference for Care Action. NCI Thesaurus. Code C148231.

The patient's decision about an intervention or a procedure offered. 